Sains Malaysiana 46(6)(2017): 867-877

http://dx.doi.org/10.17576/jsm-2017-4606-05

\title{
Pencirian Sifat Kimia Bahan Tanah pada Cerun Gagal di Sepanjang Jalan Ranau-Tambunan, Sabah, Malaysia
}

(Chemical Properties Characterization of Failed Slopes Along the Ranau-Tambunan Road, Sabah, Malaysia)

\author{
NorAn NABILla Nor AZlan,NORBERT SIMON*, AZIMAH HuSSIN, RodEANO RoSLEE \& LEE KHAI ERN
}

\begin{abstract}
ABSTRAK
Kawasan kajian yang terletak di kawasan pergunungan pantai barat Sabah sering dikaitkan dengan kejadian tanah runtuh dan kegagalan cerun. Secara geologi, kawasan di sepanjang jalan raya Ranau-Tambunan (RTM) terdiri daripada cerun potongan batuan sedimen arenit daripada Formasi Crocker dan metasedimen argilit daripada Formasi Trusmadi yang telah terluluhawa serta beberapa bahagian yang terdiri daripada endapan Aluvium Kuartener. Pencirian sifat kimia ke atas bahan cerun tanah yang gagal di kawasan tropika, terutama sekali di kawasan kajian jarang dilakukan. Pencirian ini adalah penting kerana bukan ciri fizikal bahan cerun sahaja yang mempengaruhi kejadian tanah runtuh. Oleh itu, kajian ini memberi perhatian utama kepada pencirian sifat kimia dan mineralogi lempung telah dilakukan ke atas cerun-cerun yang gagal di kawasan kajian. Bagi mencapai objektif kajian ini, sebanyak 12 sampel tanah cerun gagal yang terdiri daripada luluhawa gred VI diuji. Analisis inventori cerun gagal menunjukkan terdapat 10 kegagalan cerun tanah $(T)$ dan 8 kegagalan jenis khas (TB) dengan 3 kegagalan cerun dikelaskan berisi padu besar (> $\left.500 \mathrm{~m}^{3}\right), 7$ cerun berisi padu sederhana $\left(50-500 \mathrm{~m}^{3}\right)$ dan 2 kegagalan cerun berisi padu kecil $\left(10-50 \mathrm{~m}^{3}\right)$. Analisis kimia menunjukkan kandungan organik tanah (ВОT) yang rendah hingga sederhana daripada 3.75\%-7.23\%, pH tanah dikelaskan sebagai berasid amat tinggi hingga beralkali rendah. Analisis XRD menunjukkan komposisi mineral lempung utama terdiri daripada kaolinit dan ilit dan beberapa mineral lain seperti montmorilonit, haloisit, dickit dan vermikulit. Komposisi mineral bukan lempung utama terdiri daripada kuarza dan muskovit. Hasil kajian menunjukkan wujud perkaitan signifikan antara sifat kimia dan mineralogi tanah daripada segi pertukaran unsur kimia, hubungan air liang dan kekuatan ikatan butiran tanah dalam pembentukan mineral lempung yang menggalakkan berlakunya kegagalan cerun. Oleh itu, pembinaan dan pengurusan kerja-kerja potongan cerun bukan sahaja mengambil kira aspek sifat fizikal dan kejuruteraan tanah malah sifat kimia tanah juga amat penting terutamanya yang melibatkan batuan yang terluluhawa supaya sebarang kegagalan yang melibatkan cerun potongan dapat ditangani sewajarnya.
\end{abstract}

Kata kunci: Kegagalan cerun; luluhawa; mineral lempung; sifat kimia; Ranau-Tambunan

\section{ABSTRACT}

The study area which is located in the mountainous region of Sabah west coast is often associated with landslide and slope failure. In terms of geology, the area along the Ranau-Tambunan road (RTM) is consist of arenaceous sedimentary rocks in the Crocker Formation and weathered argiliceous meta-sedimentary rocks in the Trusmadi Formation, as well as deposit of quarternary alluvium in some parts of the study area. Characterization of chemical properties of failed materials in the tropical region, especially in the study area is seldom conducted. This characterization is important because it is not only the physical properties that influence landslide occurrences. Therefore, this study focused on the characterization of chemical characteristic and clay mineralogy on failed slope material in the study area. In order to achieve the objectives of this study, 12 soil samples from failed slopes that were categorized as grade VI in the weathering grade were tested. The inventory analysis on failed slopes showed that there were 10 failed soil slopes $(T)$ and 8 distinctive failed slopes $(T B)$ with 3 failed slopes classified as high volume (>500 $\left.\mathrm{m}^{3}\right), 7$ moderate volume $\left(50-500 \mathrm{~m}^{3}\right)$ and $2 \mathrm{small}$ volume $\left(10-50 \mathrm{~m}^{3}\right)$. The chemical analysis conducted showed low to moderate organic content (BOT) (3.75\%-7.23\%) and $\mathrm{pH}$ from highly acidic to low alkaline for the failed materials. The XRD analysis showed that the clay compositions were kaolinite, illite and several other minerals such as monmorillonite, halosite, dicktite and vermiculite. The nonclay mineral compositions were quartz and muscovite. The result showed that there is a significant association between chemical characteristics and soil mineralogy in terms of chemical changes, porewater relationship and soil bonding in clay forming minerals that induce slope failure. Therefore, construction and management of slope should not only taking into account the physical aspect and soil engineering of the soil slope, but also the chemical characteristics especially that involve weathered rocks so that any failure on slope cut can be managed appropriately.

Keywords: Clay mineral; chemical characteristic; Ranau-Tambunan; slope failure; weathering 


\section{Pengenalan}

Kawasan kajian terletak di bahagian Pantai Barat Utara Sabah iaitu di sepanjang jalan Ranau-Tambunan (RTM) yang menghubungkan daerah Ranau dan daerah Tambunan di Sabah (Rajah 1). Daerah Ranau mempunyai topografi tanah tinggi terletak di antara garisan latitud $5^{\circ} 40^{\prime} \mathrm{U}$ dan $6^{\circ} 00^{\prime} \mathrm{U}$ dan garisan longitud $116^{\circ} 15^{\prime} \mathrm{T}$ dan $116^{\circ}$ $35^{\prime} \mathrm{T}$ manakala daerah Tambunan merupakan sebuah kawasan bertopografi rendah yang terletak di bahagian pedalaman, Sabah. Secara geografinya, kawasan kajian ini dicirikan sebagai cerun-cerun tebing berbukit-bukau yang dibatasi oleh jalan raya yang menjadi penghubung utama ke daerah yang lain. Sekitar kawasan tersebut masih diliputi oleh hutan tebal dan berbukit-bukau. Kawasan ini juga sering dikaitkan dengan kejadian tanah runtuh, kegagalan cerun, mendapan, proses rayapan tanah, gelonsoran dan gelinciran tanah (Ibrahim Komoo \& Lim 2003). Boleh dikatakan kegagalan yang berlaku banyak melibatkan skala yang agak besar dan menyebabkan kerosakan jalan raya yang serius.

Aktiviti pembinaan yang giat dijalankan di kawasan tanah tinggi telah menyebabkan perubahan daripada segi sifat tabii cerun dan struktur asalan batuan dan tanah. Sehingga kini, kebanyakan pembinaan jalan raya yang melibatkan kawasan pergunungan kurang menitikberatkan faktor geologi tempatan dan sifat semula jadi batuan dan tanah yang membentuk kawasan kajian. Walaupun penstabilan semula dan penambahbaikan dibuat, namun risikonya tetap ada jika sejarah pembentukan kawasan tersebut tidak diambil kira sewajarnya. Terdapat banyak faktor yang menyumbang kepada ketidakstabilan cerun telah disenaraikan oleh pengkaji terdahulu seperti pengaruh ketakselanjaran, luluhawa dan pengaruh vegetasi (Dahal et al. 2008; Hamzah Hussin et al. 2015; Roslee et al. 2011; Varnes 1958), faktor-faktor geoteknikal seperti sifat fizikal dan kejuruteraan bahan tanah dan batuan (Damanhuri Jamalludin et al. 2014; Goh et al. 2012; 2014; Liew 2004; Majid et al. 1998; Qasim et al. 2013; Roslee et al. 2010, 2006) dan faktor manusia seperti kecuaian manusia, ketidakcekapan, kedegilan dan pelanggaran etika (Tajul Anuar 2006). Namun, kajian yang mendalam terhadap tabii bahan cerun terutamanya melibatkan sifat kimia dan mineralogi tanah-lempung yang membawa kepada ketidakstabilan cerun di kawasan tropika masih jarang dibincangkan.

Kajian mengenai sifat lempung di dalam tanah masih menjadi satu cabaran utama bagi para pengkaji terutamanya yang melibatkan kegagalan cerun. Setiap jenis tanah terdiri daripada mineral lempung yang mempunyai ciri-ciri dan kelakuan yang berbeza, maka pengaruhnya terhadap kegagalan juga berbeza. Pencirian sifat kimia tanah serta mineralogi lempung adalah berbeza disebabkan oleh pembentukan mereka.Pembentukan mineral lempung biasanya terhasil melalui proses luluhawa ataupun terjadi daripada tindak balas kegiatan hidroterma dan atau melalui proses pemendapan suatu sedimen. Di Malaysia, tanah yang terbentuk kebanyakannya merupakan hasil daripada

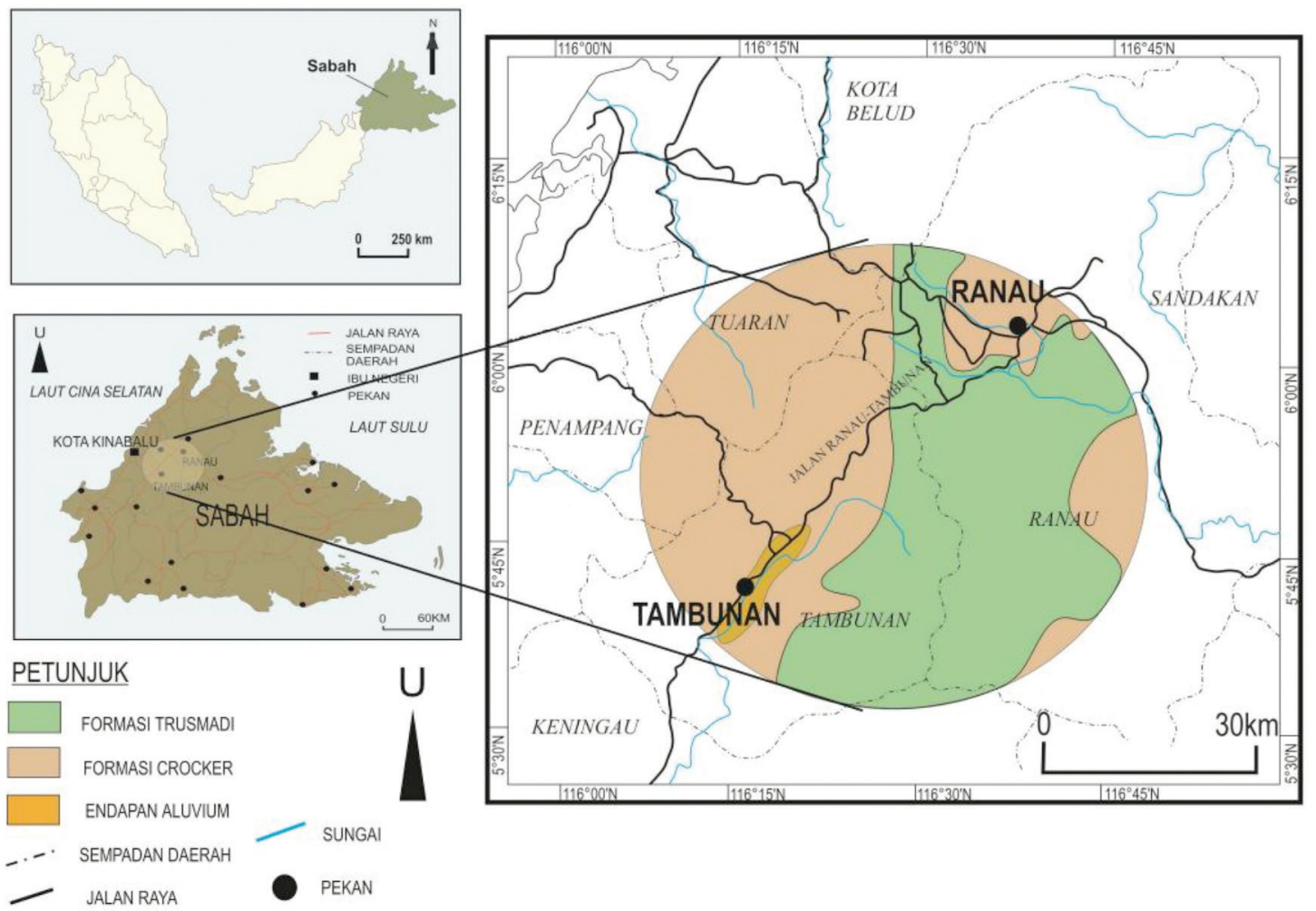

RAJAH 1. Peta kawasan kajian menunjukkan kawasan jalan raya Ranau-Tambunan yang terdiri daripada Formasi Trusmadi, Formasi Crocker dan endapan Kuaterner 
tindak balas proses luluhawa kimia (Tan 2004). Menurut Ibrahim Komoo dan Mogana (1988), keadaan luluhawa yang aktif menggalakkan proses pelemahan struktur ikatan batuan. Oleh itu, kajian ini lebih tertumpu kepada penentuan dan pencirian sifat-sifat kimia tanah serta mineralogi lempung yang mempengaruhi kegagalan cerun di sepanjang jalan raya Ranau-Tambunan, Sabah (RTM). Penentuan sifat-sifat kimia ditentukan menerusi analisis ujian kandungan bahan organik (вот), $\mathrm{pH}$ tanah, dan analisis XRD untuk mengetahui jenis-jenis bahan lempung dan bukan lempung yang hadir di dalam cerun yang gagal. Lokaliti persampelan dipilih berdasarkan kegagalan cerun yang berlaku di sepanjang jalan raya RTM (Rajah 2).

\section{GEOLOGI Di KAWASAN KAJIAN}

Kawasan kajian terdiri daripada Formasi Trusmadi (Paleosen-Eosen), Formasi Crocker (Eosen-Miosen) dan Endapan Kuartener. Formasi Trusmadi mengandungi batuan argilit berwarna gelap samada berlapisan tebal atau berselang lapis dengan batu pasir. Menurut Jacobson (1970), beliau membahagikan urutan batuan dalam Formasi Trusmadi kepada empat unit litologi utama iaitu batuan argilit, susunan selang-lapis (turbidit), kataklastik dan batu pasir masif. Formasi Trusmadi dicirikan sebagai batuan argilit berwarna gelap, batu lodak dan turbidit berlapisan nipis dalam urutan yang berstrata. Beberapa kawasan di dalam Formasi Trusmadi telah termetamorf kepada fasies syis-hijau bergred rendah kemudian menjadi batuan sabak, filit dan meta-arenit. Batu syal segar berwarna kelabu gelap tetapi berubah kepada kelabu cair dan kecoklatan apabila terluluhawa (Roslee et al. 2011). Tongkul (2006) melaporkan unit batuan Trusmadi terdiri daripada batuan meta-arenit yang telah tericih dan berubah bentuk, sabak dan filit yang terletak berhampiran dengan kawasan Ranau. Lipatan dan sesar yang berlaku pada batuan tersebut, menghasilkan penyusunan dan pertindihan lapisan sedimen (Tongkul 1990).

Formasi Crocker dicirikan oleh batu pasir kelabu nipis hingga tebal yang berselang-lapis dengan batu lodak, batu lumpur, syal merah dan kelabu (Collanette 1958; Jacobson 1970; Roslee et al. 2011). Batu pasir pada formasi ini biasanya adalah berbutir halus hingga sangat halus dan mempunyai retakan yang banyak manakala batu syal telah tericih (Roslee et al. 2006). Unit syal terdiri daripada jenis syal merah dan kelabu. Pembentukan batuan Formasi Crocker terendap di kawasan laut dalam pada usia Oligosin hingga awal Miosin kemudiannya berlakunya aktiviti tektonik pada pertengahan Miosin menyebabkan terjadinya lipatan dan sesar (Zulfahmi 1999). Menurut Tongkul (1987), tektonik major pada pertengahan Miosen menghasilkan arah daya mampatan NW-SE yang memberi kesan perubahan seperti lipatan dan sesar kepada Formasi Crocker. Pembentukan Trusmadi umumnya menunjukkan dua orientasi struktur utama NW-SE dan NE-SW (Tongkul 2007).

Endapan kuartener ialah endapan tanah aluvium yang masih terendap hingga kini. Menurut Roslee et al. (2008), tanah aluvium mewakili sedimen aluvial tak terkukuh di teres sungai dan bahan produk luluhawa yang terdiri daripada tidak terisih hingga berisihan baik, pasir, lodak dan lempung dengan perkadaran yang berbeza-beza yang

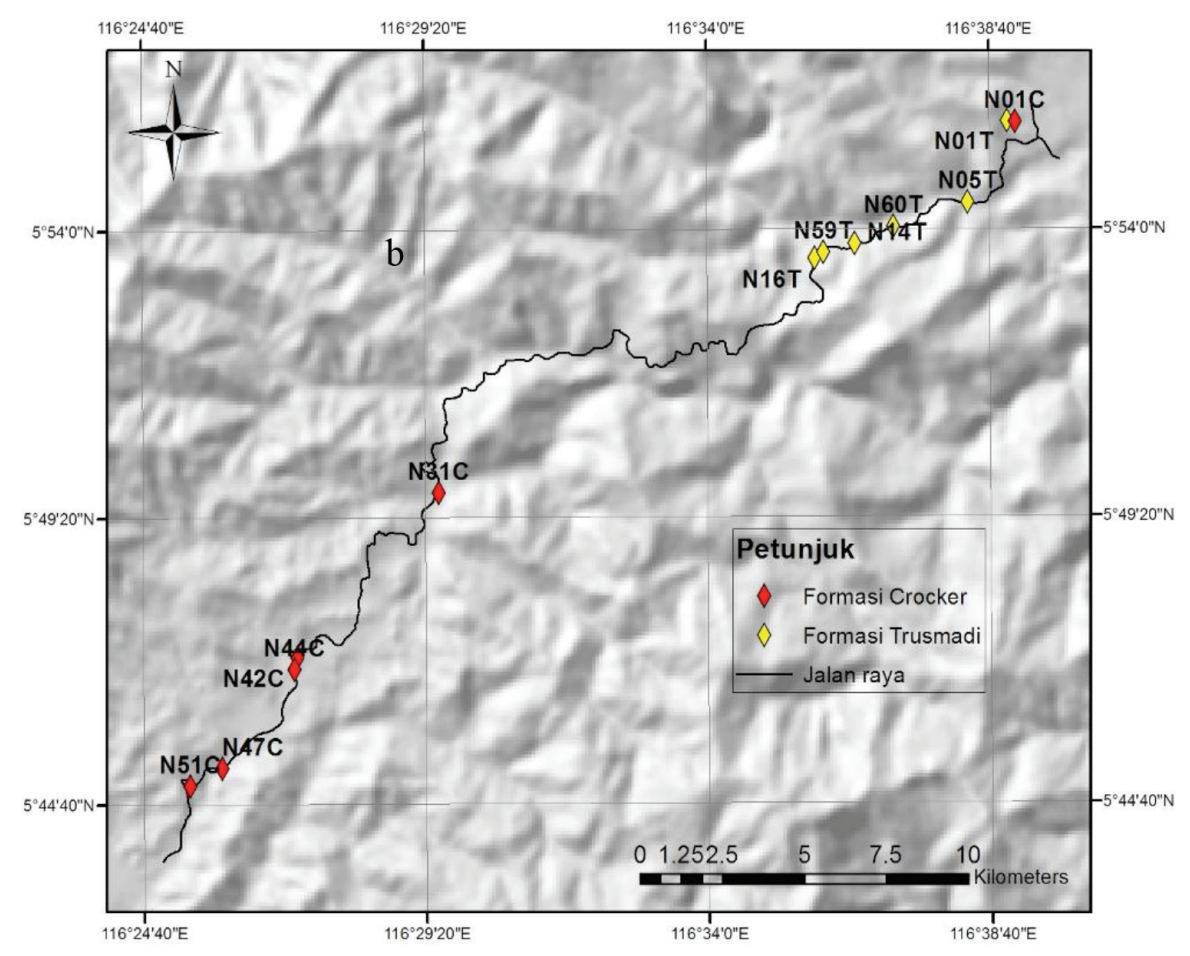

RAJAH 2. Lokaliti persampelan cerun gagal bagi Formasi Crocker dan Formasi Trusmadi di sepanjang RTM 
berasal daripada batuan dasar. Ia berlaku dalam kanta yang tidak teratur yang berbeza-beza daripada segi bentuk dan ketebalan. Aluvium juga terdiri daripada lapisan bahan organik yang sangat nipis dan disifatkan sebagai lembut, mampat dan boleh terdedah kepada mendapan.

\section{BAHAN DAN KAEDAH KAJIAN}

\section{KERJA LAPANGAN}

Fasa kerja lapangan melibatkan tiga (3) peringkat: peringkat pertama, inventori kegagalan cerun tanah dan cerapan lapangan di sepanjang RTM meliputi cerapan litologi, geologi am, komponen aktiviti cerun, jenis kegagalan, isi padu cerun gagal dan sudut cerun direkodkan. Pada peringkat kedua pula, pengenalpastian bahan tanah pada kedua-dua formasi dibuat merangkumi warna (Munsell 1941), keadaan air permukaan tanah, tumbuhan penutup cerun, gred luluhawa (IAEG 1981) dan kekuatan tanah di lapangan (Brown 1981). Pada peringkat ketiga, pengambilan sampel tanah terganggu bagi tujuan uji kaji makmal dilakukan. Persampelan sampel tanah hanya dilakukan pada bahan gred luluhawa VI. Bahan tanah pada cerun dikorek dengan kedalaman satu hingga dua kaki atau 100 mm dari permukaan satah gagal (Damanhuri Jamalludin et al. 2014; McKenna et al.2011). Pensampelan tanah dibuat dengan membuang permukaan tanah paling atas (bahan gagal) dan kemudian sampel tanah diambil sebanyak 2.0-2.5 kg dan dimasukkan ke dalam plastik kedap udara sebelum dibawa ke makmal.

Komponen aktiviti cerun di kawasan kajian merangkumi sebarang aktiviti yang melibatkan penggunaan cerun seperti potongan cerun jalan raya, pemotongan dan pengorekan cerun bukit bagi tujuan, pencuraman kaki cerun dan penebingan cerun jalan raya. Jenis kegagalan cerun ditentukan berdasarkan pengelasan kegagalan cerun yang dicadangkan oleh Ibrahim Komoo (1985). Kegagalan cerun dikategorikan kepada tiga kelas utama iaitu kegagalan jenis tanah $(\mathrm{T})$, kegagalan jenis batuan (B) dan kegagalan jenis khas (TB). Namun, hanya kegagalan yang melibatkan bahan tanah sahaja yang dipertimbangkan dalam kajian ini. Kegagalan jenis tanah dibahagikan kepada gelinciran (T1), gelonsoran (T2), aliran (T3), rayapan (T4) dan kegagalan kompleks (T5) manakala kegagalan jenis khas pula diklasifikasikan sebagai kegagalan hakisan (TB1). Isi padu kegagalan cerun dikelaskan kepada tiga kategori iaitu isi padu besar $\left(>500 \mathrm{~m}^{3}\right)$, isi padu sederhana $\left(50-500 \mathrm{~m}^{3}\right)$ dan isi padu kecil $\left(10-50 \mathrm{~m}^{3}\right)$ berdasarkan dimensi lebar cerun $\times$ tinggi muka cerun $\times$ kedalaman bahan gagal. Sudut kecuraman cerun pula ditentukan melalui pemerhatian di lapangan.

\section{KANDUNGAN BAHAN ORGANIK TANAH}

Penentuan bahan organik tanah dijalankan mengikut kaedah BS 1377-3:1990 Part 3. Sebanyak 10 mL hidrogen peroksida $\left(\mathrm{H}_{2} \mathrm{O}_{2}\right)$ menggantikan kalium dikromat dan sulfat ferus dititiskan ke dalam $10 \mathrm{~g}$ tanah kering untuk menghapuskan bahan organik dalam tanah. Penyediaan sampel ini dilakukan di dalam bilik kebuk wasap. Kehadiran gelembung udara adalah disebabkan wujudnya interaksi antara bahan organik dalam tanah dan hidrogen peroksida. Sekiranya tiada tindak balas berlaku, sampel tanah ini dipanaskan di atas 'sandbath' dan dibiarkan selama 24 jam. $\mathrm{H}_{2} \mathrm{O}_{2}$ akan ditambah pada keesokan harinya bagi memastikan tindak balas lengkap. Sebanyak $150 \mathrm{~mL}$ air suling ditambah ke dalam bikar, digoncangkan dan dibiarkan selama 24 jam. Pada hari berikutnya, kesemua cecair yang berada di dalam bikar dipipet keluar dan sampel dikeringkan di dalam oven bersuhu $105^{\circ} \mathrm{C}$ selama 24 jam. Berat akhir sampel ditimbang dan dicatatkan. Pengelasan BOT dilakukan seperti yang dicadangkan oleh Acres et al. (1975) (Jadual 1a).

\section{KANDUNGAN pH TANAH}

Kaedah uji kaji nilai $\mathrm{pH}$ tanah dijalankan mengikut piawaian BS 1377-3:1990 Part 3. Ujian ini dijalankan untuk menentukan sifat tanah sama ada berasid, neutral dan beralkali. Pengelasan nilai $\mathrm{pH}$ adalah berdasarkan U.S Department of Agriculture (1998) (Jadual 1b). Sebanyak $10 \mathrm{~g}$ tanah segar ditimbang dan dimasukkan ke dalam bikar $50 \mathrm{~mL}$. Sebanyak $25 \mathrm{~mL}$ air suling dimasukkan ke dalam bikar tersebut. Air dan tanah dihomogenkan dengan menggunakan rod kaca. Campuran air suling dan tanah dibiarkan selama semalaman. Selepas itu, bacaan diambil dengan menggunakan $\mathrm{pH}$ meter model Hanna Instrumen HI 2211. Bacaan direkodkan dan ujian diulang sebanyak empat kali dengan menggunakan kaedah yang sama untuk mendapatkan purata nilai $\mathrm{pH}$ tanah.

\section{ANALISIS PEMBELAUAN SINAR-X (XRD)}

Menerusi analisis pembelauan sinar- $X$ ini dapat ditentukan jenis mineral yang memberi pengaruh kepada sifat kelakuan tanah. Keputusan bagi komposisi mineral lempung dan mineral bukan lempung diperoleh daripada analisis pembelauan sinar- $\mathrm{X}$ tanpa dirawat pada julat imbasan $2 \theta=5^{\circ}-80^{\circ}$ pada kadar $1^{\circ}$ seminit menggunakan sinaran katod kuprum. Jenis mineral ditentukan melalui pemadanan pola belauan bahan piawai yang telah disediakan oleh JCPDS atau perisian XRD.

\section{HASIL DAN PERBINCANGAN}

\section{INVENTORI KEGAGALAN CERUN}

Bahan cerun potongan yang mengalami kegagalan di kawasan kajian adalah jenis tanah. Jenis kegagalan cerun ditentukan berdasarkan pengelasan kegagalan cerun yang dicadangkan oleh Ibrahim Komoo (1985). Terdapat dua jenis kegagalan yang telah dikenal pasti iaitu kegagalan cerun tanah (T) dan kegagalan jenis khas (TB) (Rajah 3). Tiga kegagalan cerun dikelaskan sebagai berisi padu besar $\left(>500 \mathrm{~m}^{3}\right.$ ) dan tujuh cerun berisi padu sederhana (50-500 $\mathrm{m}^{3}$ ) dan dua kegagalan cerun berisi padu kecil (10-50 $\mathrm{m}^{3}$ ). Kegagalan jenis (T) diperhatikan di stesen cerun N01C, 
JADUAL 1. (a) Skema pengelasan kandungan bahan organik tanah yang dicadangkan oleh Acres et al. (1975) dan (b) Pengelasan pH tanah yang dicadangkan oleh USDA (1998)

\begin{tabular}{cllc}
\hline \multicolumn{2}{c}{ B) } & \multicolumn{1}{c}{ bahan organik tanah } & \multicolumn{1}{c}{$\mathrm{pH}$ tanah } \\
\hline $\begin{array}{c}\text { Kandungan bahan } \\
\text { organik (BOT) } \%\end{array}$ & \multicolumn{1}{c}{$\begin{array}{c}\text { Pengelasan } \\
\text { (Acres et al. 1975) }\end{array}$} & \multicolumn{1}{c}{ Kumpulan } & Julat pH tanah \\
\hline$>20$ & Sangat tinggi & Beralkali tinggi & $8.5-9.0$ \\
$10-20$ & Tinggi & Beralkali sederhana & $7.9-8.4$ \\
$4-10$ & Sederhana & Beralkali rendah & $7.4-7.8$ \\
$2-4$ & Rendah & Neutral & $6.6-7.3$ \\
$<2$ & Sangat rendah & Berasid rendah & $6.1-6.5$ \\
& & Berasid sederhana & $5.6-6.0$ \\
& & Berasid tinggi & $5.1-5.5$ \\
& & Berasid amat tinggi & $4.5-5.0$ \\
& & Ekstrem berasid & $3.5-4.4$ \\
\hline
\end{tabular}
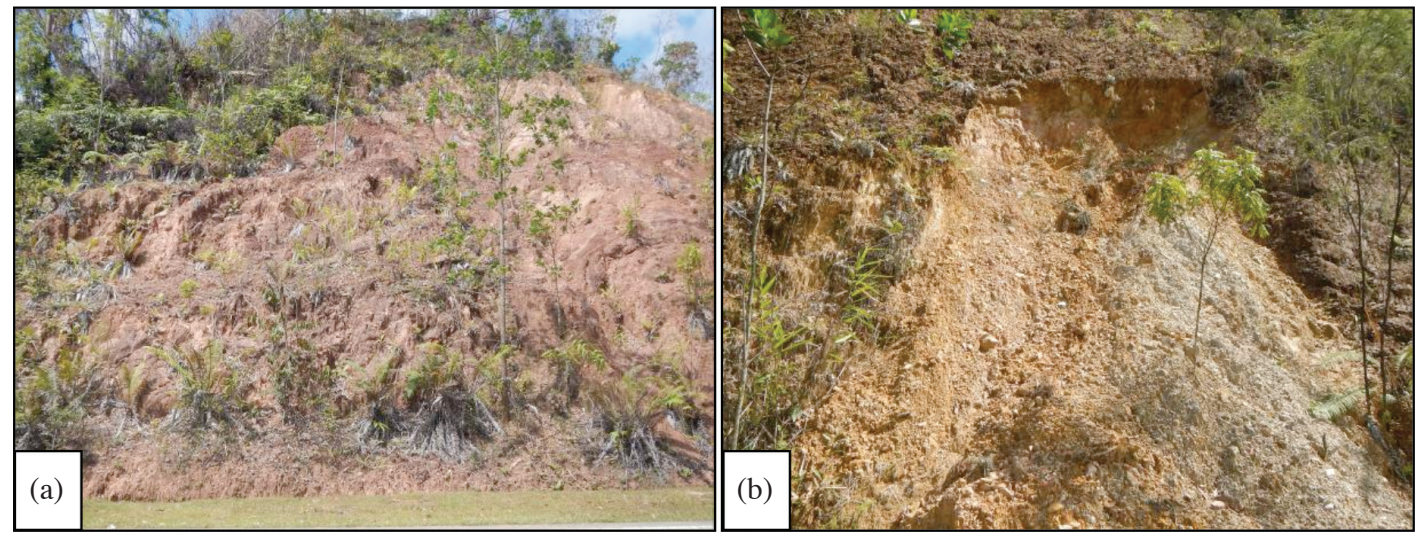

RAJAH 3. (a) Kegagalan hakisan takar dan alur (TB1-b) pada cerun lokaliti N51C dan (b) Kegagalan jenis puing (T3-b) pada cerun N44C

N31C, N44C, N47C, N01T, N05T, N14T dan N16T manakala kegagalan jenis (TB) pula diperhatikan pada stesen cerun N01C, N42C, N51C, N01T, N16T, N59T dan N60T. Kegagalan yang berlaku melibatkan komponen aktiviti seperti cerun potongan jalan raya, penambakan cerun potongan dan tebing jalan raya, pengorekan dan pencuraman kaki cerun dan perlindungan cerun. Kegagalan jenis tanah $(\mathrm{T})$ yang dikenal pasti adalah jenis gelinciran cetek (T1-a), gelonsoran tunggal (T2-a), aliran tanah (T3-a) dan aliran puing (T3-b) manakala kegagalan hakisan (TB) adalah jenis hakisan keping (TB1-a) dan hakisan takar serta alur (TB1-b) atau dikenali sebagai gully erosion (Roslee et al. 2011) (Jadual 2).

Kedalaman bahan yang gagal kebanyakannya dipengaruhi oleh gred luluhawa tinggi (gred VI). Cerun N31C dan N14T yang mengalami kegagalan tebing jalan raya dikelaskan sebagai aliran tanah (T3-a). Kegagalan jenis aliran tanah (T3-a) dikesan pada cerun potongan yang biasanya berpunca daripada air tanah tepu dan penyaliran air tanah yang kurang baik. Cerun gagal yang berskala besar menunjukkan beberapa jenis siri kegagalan yang telah berlaku seperti kegagalan jenis T2-a, T3-a dan TB1-a pada cerun N01C dan N01T serta kegagalan hakisan (TB1-a dan TB1-b) pada cerun N42C. Ditafsirkan faktor kegagalan yang berlaku di kawasan tersebut dipengaruhi faktor geologi dan sejarah aktiviti tektonik semasa dan selepas pembentukan batuan tersebut dengan kewujudan zon sesar dan ketakselarasan pada stesen cerun N01C dan N01T (Rajah 4). Selain itu, kegagalan cerun tanah juga dipengaruhi oleh kesan struktur dan ketakselanjaran pada dinding cerun, sudut kecuraman $>45^{\circ}$ serta beban galas yang tinggi. Kegagalan hakisan yang hanya melibatkan hakisan tumbuhan penutup dan tanah permukaan cerun dikenal pasti sebagai hakisan keping. Hakisan takar dan alur pula menunjukkan alur hakisan pada permukaan cerun yang disebabkan oleh larian air permukaan cerun melalui kesan ketakselanjaran atau satah bukaan pada dinding cerun yang dikesan pada stesen N42C dan N51C pada cerun Formasi Crocker.

\section{LULUHAWA BAHAN GAGAL}

Proses perubahan dan luluhawa batuan memainkan peranan yang penting dalam kehadiran mineral lempung di dalam tanah. Bahan cerun potongan di kawasan kajian terdiri daripada bahan batuan dan tanah yang terluluhawa tinggi (gred IV) hingga tanah baki (gred VI). Namun, kebanyakan cerun yang mengalami kegagalan adalah 


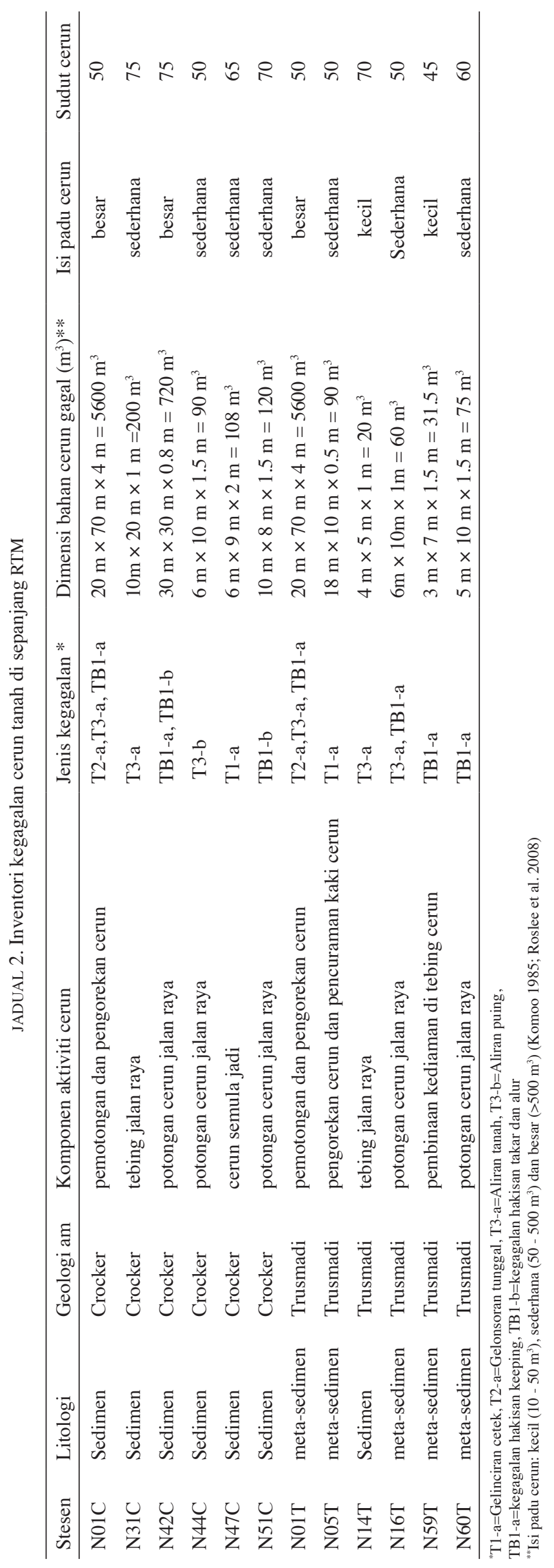



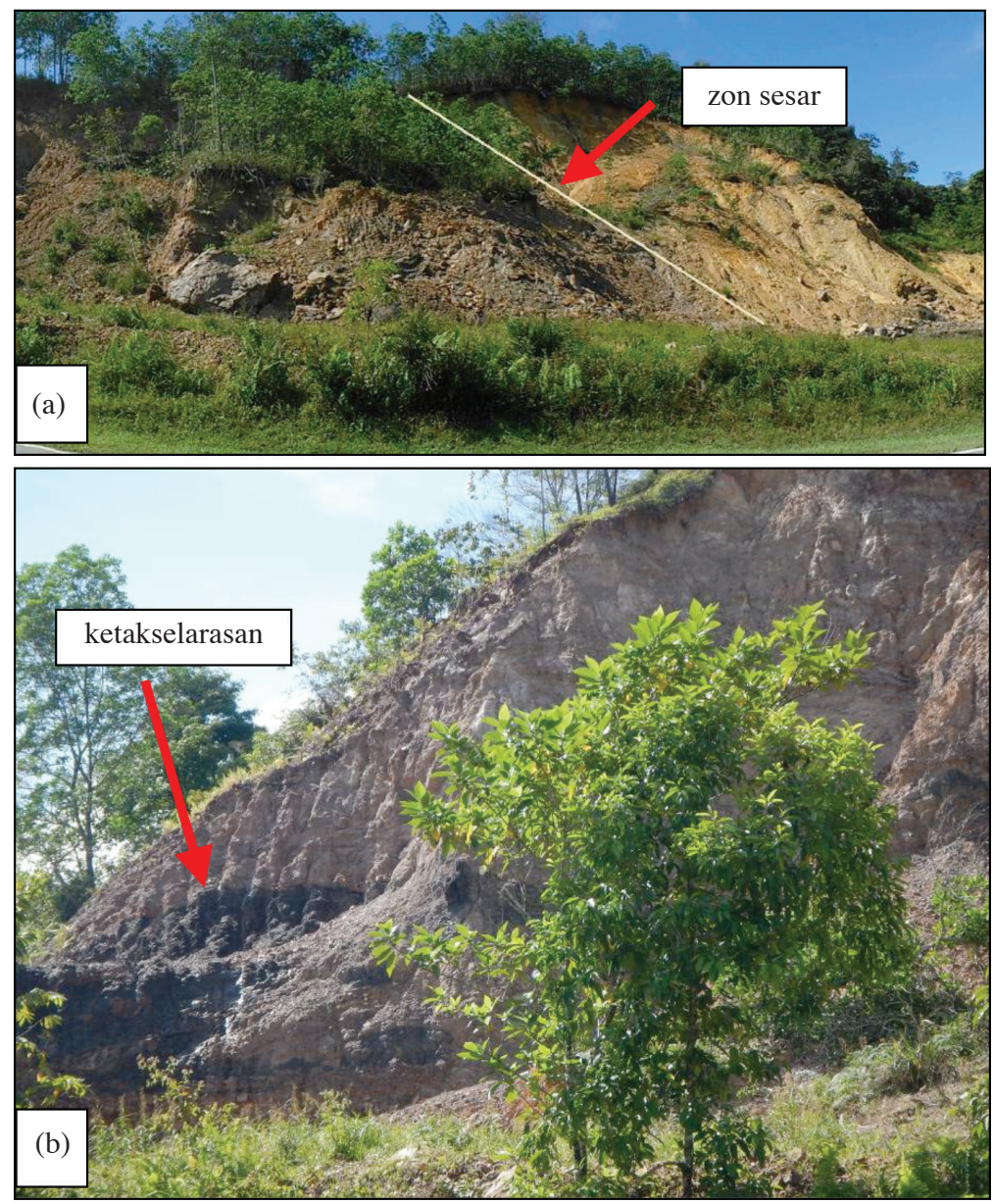

RAJAH 4. Kewujudan zon sesar (a) dan ketakselarasan (b) pada stesen cerun N01C dan N01T menunjukkan aktiviti geologi berlaku di kawasan ini

terdiri daripada bahan tanah, oleh itu, persampelan tanah dibuat ke atas produk luluhawa batuan sedimen dan metasedimen luluhawa penuh (gred V) dan tanah baki (gred VI) sahaja kerana pada profil luluhawa ini mengandungi bahan lempung yang mempengaruhi sifat kelakuan tanah. Tahap luluhawa pada cerun potongan diperhati berdasarkan ciri-ciri seperti warna, struktur bahan cerun dan kekuatan fizikal (Zulfahmi et al. 2007). Perbezaan warna dapat dilihat dengan jelas pada cerun tanah Formasi Crocker dan Formasi Trusmadi. Tanah Formasi Crocker dilihat berwarna coklat cerah hingga coklat kekuningan. Tanah bagi Formasi Trusmadi dilihat berwarna gelap lebih kepada kelabu gelap kehitaman dan beberapa bahagian berwarna kecoklatan disebabkan kehadiran oksida besi.

Jadual 3 menunjukkan hasil cerapan bahan cerun tanah gagal yang diambil pada 12 buah cerun gagal di sepanjang RTM. Beberapa faktor yang mempengaruhi jenis kegagalan telah dikenal pasti iaitu kedalaman profil luluhawa tinggi, kekuatan bahan cerun terhadap agen luluhawa, kekurangan penutup tumbuhan pada permukaan cerun, pemotongan sudut kemiringan muka cerun $>45^{\circ}$ dan aliran air permukaan yang menyebabkan berlakunya hakisan.

\section{UJIAN MAKMAL}

\section{BOT DAN $p H$ TANAH}

Jadual 4 menunjukkan ringkasan analisis kimia dan mineralogi tanah berdasarkan jenis kegagalan dan formasi batuan. Kandungan \% BOT di kawasan kajian juga menunjukkan julat yang rendah iaitu $(3.75 \%-7.25 \%)$. Namun, berdasarkan pengelasan вОт yang dicadangkan oleh Acres et al. (1975), \% BOT pada sampel cerun gagal di kawasan kajian boleh dikelaskan sebagai sederhana (4.0\%-10.0\%). Nilai pH tanah pula menunjukkan julat dari 3.49-7.54. Berdasarkan pengelasan $\mathrm{pH}$ tanah oleh U.S Department of Agriculture (USDA) (1998), sampel tanah Formasi Crocker mempunyai keasidan amat tinggi berjulat dari 4.57 hingga 4.80. Manakala sampel Formasi Trusmadi mempunyai nilai $\mathrm{pH}$ yang neutral hingga alkali rendah iaitu dari 7.09 hingga 7.54 kecuali sampel N01T yang mempunyai keasidan yang ekstrem iaitu di bawah 3.50. Kandungan \% вот bagi sampel kegagalan cerun khas (TB) (4.00-7.23) pula menunjukkan julat yang lebih tinggi berbanding kegagalan cerun tanah (T) (3.75-5.97). Namun, nilai $\mathrm{pH}$ tanah pula tidak dipengaruhi jenis kegagalan yang terbentuk. 
JADUAL 3. Hasil cerapan bahan cerun tanah luluhawa di lapangan

\begin{tabular}{lcccc}
\hline $\begin{array}{c}\text { Stesen/ } \\
\text { Sampel }\end{array}$ & $\begin{array}{c}\text { Gred luluhawa } \\
\text { (IAEG 1981) }\end{array}$ & \multicolumn{1}{c}{$\begin{array}{c}\text { Warna } \\
\text { (Munsell 1941) }\end{array}$} & $\begin{array}{c}\text { Keadaan air } \\
\text { permukaan tanah }\end{array}$ & $\begin{array}{c}\text { Tumbuhan } \\
\text { kekuatan tanah } \\
\text { di lapangan } \\
\text { (Brown 1981) }\end{array}$ \\
\hline N01 C & V/VI & coklat cerah kekuningan & mengalir & Jarang \\
N31 C & VI & coklat kekuningan & lembap & Sederhana \\
N42 C & VI & coklat cerah kemerahan & kering & Jarang \\
N44 C & VI & kuning kecoklatan, putih kekelabuan & lembap & Sederhana \\
N47 C & VI & kuning kecoklatan, putih kekelabuan & kering & Sederhana \\
N51 C & VI & coklat kekuningan & kering & Jarang \\
N01 T & V/VI & kelabu gelap hingga kehitaman & lembap & Jarang \\
N05 T & V/VI & coklat kekelabuan, kelabu cerah & basah & Jarang \\
N14 T & VI & coklat kekuningan & lembap & Sederhana \\
N59 T & VI & kelabu gelap & lembap & Sederhana \\
N60 T & VI & kelabu gelap hingga kehitaman & lembap & Sederhana \\
N16 T & V/V1 & kelabu gelap hingga kehitaman & lembap & Jarang \\
\hline
\end{tabular}

Majoriti bahan tanah di kawasan kajian terdiri daripada cerun potongan yang terdedah kepada pelbagai agen luluhawa yang menyebabkan hakisan. Hal ini berpunca daripada kekurangan tumbuh-tumbuhan untuk mengikat struktur tanah pada permukaan cerun. Oleh itu, kekurangan BOT dan kekerapan perubahan cuaca menyebabkan hakisan tanah berlaku seterusnya berlakunya kegagalan cerun. Formasi Trusmadi dilihat mempunyai kandungan \% вот (3.49-7.23) yang lebih tinggi berbanding Formasi Crocker (4.07-5.95). Kajian yang dilaporkan oleh Yong (2008) menunjukkan kandungan вот di kawasan kajian adalah rendah (2.19\%-3.16\%). Berdasarkan pemerhatian di lapangan, kebanyakan cerun potongan Formasi Trusmadi dilihat terdiri daripada pokok-pokok kecil atau tumbuhan yang bertindak sebagai penutup permukaan cerun pada beberapa bahagian cerun berbanding cerun tanah pada Formasi Crocker yang kebanyakkannya lebih terdedah dan tumbuhan hanya ditemui pada celah-celah alur hakisan tanah. Kehadiran humus hasil daripada penguraian bahan organik dalam tanah turut mempengaruhi tahap keasidan tanah. Nilai $\mathrm{pH}$ tanah yang diperoleh menunjukkan keasidan tanah pada cerun Formasi Trusmadi mengawal kebolehlarutan nutrien dalam mempengaruhi peratusan kandungan bahan organik kerana kehadiran bahan organik dalam tanah kebanyakannya ideal pada $\mathrm{pH} 6$ hingga 7 iaitu pada keasidan neutral.

\section{KOMPOSISI MINERAL (XRD)}

Hasil XRD menunjukkan kelimpahan komposisi lempung utama kaolinit dan ilit (Jadual 5). Kehadiran mineral ini mencadangkan kewujudannya yang terhasil daripada proses luluhawa ke atas mineral utama iaitu feldspar dan muskovit yang membentuk batuan dasar formasi ini. Haloisit merupakan mineral lempung daripada kumpulan kaolin. Boleh dilihat kehadiran haolisit hanya dikesan pada sampel cerun gagal Formasi Crocker. Kewujudan mineral daripada kumpulan kaolin seperti kaolinit, dickit dan haloisit adalah lebih banyak pada Formasi Crocker jika dibandingkan dengan Formasi Trusmadi yang dikesan hanyalah mineral kaolinit. Montmorilonit daripada kumpulan smektit juga wujud pada dua sampel iaitu N01T dan N16T. Begitu juga sampel daripada tanah cerun Formasi Crocker dengan komposisi mineral lempung yang paling banyak dikesan iaitu kaolinit dan ilit. Ilit yang dikesan mempunyai peratusan kelimpahan yang tinggi berbanding kaolinit dan bersistem hablur monoklinik. Mineral montmorilonit pula tidak dapat dikesan pada Formasi Crocker. Walau bagaimanapun, mineral lempung lain yang dikesan ialah dickit, vermikulit, haloisit dan sanidin. Keamatan puncak mineral muskovit dan sanidin dalam difrakogram sampel lempung mungkin disebabkan saiz zarah yang amat kecil sehingga saiz lempung. Merujuk kepada kelimpahan mineral bukan lempung pula, mineral kuarza dan muskovit merupakan mineral paling dominan. Bagi sampel $<63 \mu \mathrm{m}$, keputusan menunjukkan keamatan puncak tertinggi ialah kuarza dan diikuti muskovit, albit, dolomit dan magnetit sebagai mineral aksesori.

Sampel tanah kegagalan jenis khas (TB) dilihat mengandungi mineral lempung seperti kaolinit, ilit, montmorilonit dan halosit begitu juga dalam sampel kegagalan jenis tanah $(\mathrm{T})$ dengan kehadiran beberapa mineral lempung lain seperti vermikulit dan dickit (Jadual 5). Ini menunjukkan kelimpahan mineral lempung pada bahan terluluhawa tinggi menyebabkan perubahan daripada segi kelakuan fizikal tanah apabila terdedah kepada faktor-faktor kegagalan seperti kehadiran air permukaan tanah, pengaruh bahan organik dan sebagainya.

\section{PERBINCANGAN}

Cuaca memainkan peranan yang besar dalam siri kegagalan yang berlaku, terutamanya pada persekitaran beriklim tropika yang menggalakkan perubahan dan pertukaran unsur kimia dan fizikal tanah. Perubahan warna di beberapa bahagian profil cerun juga menunjukkan proses perubahan yang berlaku disebabkan tindak balas sifat 
JADUAL 4. Ringkasan analisis kimia dan mineralogi tanah berdasarkan jenis kegagalan dan formasi batuan

\begin{tabular}{lcccc}
\hline \multirow{2}{*}{ Sifat kimia/mineralogi } & \multicolumn{2}{c}{ Formasi } & \multicolumn{2}{c}{ Jenis kegagalan } \\
\cline { 2 - 5 } & Crocker & Trusmadi & Jenis tanah & Jenis khas (hakisan) \\
\hline BOT $(\%)$ & $4.07-5.95$ & $3.75-7.23$ & $3.75-5.97$ & $4.00-7.23$ \\
pH & $4.57-4.80$ & $3.49-7.54$ & $3.49-7.54$ & $3.49-7.45$ \\
Lempung $(<2 \mu \mathrm{m})$ & K, I, H, D & K, I, Mo, V & K, I, H, Mo, V, D & K, I, Mo, H \\
Bukan lempung $(<63 \mu \mathrm{m})$ & Q, M, Mag & Q, M, Do, Al, G, Mag & Q, M, Do, Al, Mag & Q, M, Mag, G \\
\hline
\end{tabular}

*K=kaolinit, $\mathrm{I}=\mathrm{ilit}, \mathrm{H}=$ halosit, $\mathrm{Mo}=$ montmorilonit, $\mathrm{V}=$ =vermikulit, $\mathrm{D}=$ dickit

** $\mathrm{Q}=$ kuarza, $\mathrm{M}=$ muskovit, $\mathrm{Do}=$ dolomit, $\mathrm{Al}=$ albit, $\mathrm{Mag}=$ magnetit, $\mathrm{G}=$ ganterit

JADUAL 5. Rumusan hasil analisis sifat kimia yang dikaji

\begin{tabular}{lclllll}
\hline \multirow{2}{*}{$\begin{array}{l}\text { No } \\
\text { sampel }\end{array}$} & pH & USDA 1998 & BOT\% & $\begin{array}{c}\text { Acres et al. } \\
\text { (1975) }\end{array}$ & \multicolumn{1}{c}{$<2 \mu \mathrm{m}$} & XRD \\
\hline N01C & 4.74 & Berasid amat tinggi & 5.97 & Sederhana & kaolinit, ilit & kuarza, muskovit \\
N31C & 4.78 & Berasid amat tinggi & 5.34 & Sederhana & kaolinit, muskovit, sanidin & kuarza, muskovit \\
N42C & 4.68 & Berasid amat tinggi & 4.66 & Sederhana & ilit & kuarza, magnetit \\
N44C & 4.57 & Berasid amat tinggi & 5.95 & Sederhana & kaolinit, haloisit & kuarza \\
N47C & 4.66 & Berasid amat tinggi & 5.53 & Sederhana & dickit & Kuarza, muskovit \\
N51C & 4.80 & Berasid amat tinggi & 4.07 & Sederhana & kaolinit, ilit, haloisit & kuarza \\
N01T & 3.49 & Ekstrem berasid & 4.00 & Sederhana & kaolinit, ilit, montmorilonit & kuarza, muskovit \\
N05T & 7.54 & Beralkali rendah & 3.75 & Rendah & kaolinit, ilit, vermikulit & kuarza, muskovit, dolomit, albit \\
N14T & 7.09 & Neutral & 5.61 & Sederhana & kaolinit, ilit, vermikulit & kuarza, muskovit \\
N59T & 7.45 & Beralkali rendah & 6.89 & Sederhana & kaolinit, ilit & kuarza, muskovit, ganterit \\
N60T & 7.30 & Neutral & 7.23 & Sederhana & kaolinit, ilit & kuarza, muskovit \\
N16T & 7.45 & Beralkali rendah & 5.03 & Sederhana & Kaolinit, ilit, montmorilonit & Muskovit, magnetit \\
\hline
\end{tabular}

kimia tanah dan suhu terhadap mineralogi tanah. Mineral yang terbentuk pada persekitaran suhu dan tekanan yang rendah lebih mudah terluluhawa apabila terdedah kepada permukaan. Oleh itu, bahan tanah yang terluluhawa adalah tidak stabil dan boleh mengalami kegelinciran disebabkan oleh tekanan liang tinggi dan proses geomorfologi yang intensif (Roslee et al. 2008). Tahap luluhawa yang tinggi ke atas batuan metasedimen Formasi Trusmadi yang terdiri daripada batuan syal, selang-lapis nipis turbidit dan batuan bertekstur keping seperti filit menyebabkan struktur ikatan batuan pada muka cerun menjadi lemah apabila terdedah seterusnya berlakunya hakisan pada permukaan cerun. Kegagalan cerun Formasi Crocker pula kebanyakannya dikawal oleh kesan struktur ketakselanjaran dan aktiviti tektonik seperti kewujudan zon sesar, set-set kekar dan ketakselarasan.

Proses luluhawa ke atas batuan menyebabkan batuan berubah kepada tanah dan lempung. Tanah Formasi Trusmadi berargilit mengandungi lempung kaolinit, ilit, vermikulit dan montmorilonit manakala bahan tanah Formasi Crocker mengandungi lempung kaolinit dan haloisit. Kehadiran mineral lempung ini bergantung kepada komposisi mineralogi asalan batuan. Walaupun dalam peratusan yang sedikit, kehadirannya memberi impak yang besar dalam kestabilan bahan tanah. Kehadiran mineral montmorilonit memberi pengaruh yang besar kepada ketidakstabilan cerun. Dalam kajian ini, mineral montmorilonit dikesan ialah $>10 \%$ pada sampel tanah N01T dan N16T pada sampel Formasi Trusmadi. Mineral smektit boleh menyerap molekul air di antara lapisan individu silikat justeru menghasilkan rintangan geseran yang rendah dan pengembangan struktur mineral yang tinggi seterusnya berkembang dan melonggarkan struktur ikatan. Mineral lempung jenis berkembang seperti montmorilonit walaupun dalam peratusan kecil dalam fabrik dan struktur ikatan boleh menyebabkan pengembangan dalam tingkah laku lempung seterusnya meningkatkan sifat keplastikan bahan tanah (Vacandios et al.2007). Ilit merupakan mineral silikat (kebiasaannya feldspar) yang paling dominan dalam batuan argilit yang telah terluluhawa. Kelimpahnya di dalam kedua-dua formasi adalah disebabkan daripada perubahan mineral asal seperti muskovit. Kaolinit merupakan mineral lempung tidak aktif yang stabil yang mempunyai sifat kebolehjerapan air yang rendah. Namun, sifatnya yang mudah pecah dan terurai apabila terdedah kepada agen luluhawa seperti air mengakibatkan pengembangan bahan lempung yang boleh menyebabkan kegagalan cerun (Roslee et al. 2010). Kehadiran kaolinit juga menandakan tanah telah berada di fasa terakhir proses luluhawa (Siti Nurshakiren 2010; Zulfahmi et al. 2012). Proses luluhawa terhadap mineral feldspar kepada kaolinit membenarkan sebahagian unsur utama Si dalam tanah berpasir digantikan dengan Al. Pertukaran cas negatif ini menyebabkan penyeimbangan kation berlaku dengan kehadiran unsur seperti K, Ca dan Na. Ini menyebabkan kekuatan ikatan antara mineral menjadi lemah dan berlaku pembentukan liang di antara zarah mineral (Roslee et al. 2008). 
Perbezaan kandungan вот yang sedikit antara Formasi Trusmadi dan Formasi Crocker turut memberi kesan kepada kegagalan yang berlaku daripada segi litologi, jenis dan kedalaman kegagalan yang terlibat. Selain itu, kehadiran beberapa mineral lempung dalam tanah yang boleh menjerap lembapan adalah kurang dan menyebabkan bahan organik yang berasosiasi dengan tanah menjadi kering dan mudah terhakis. Sifat kebolehjerapan tanah yang rendah memudahkan kehadiran dan kehilangan kandungan lembapan dalam tanah menyebabkan struktur dalaman menjadi lemah dan hakisan seperti hakisan keping atau takar dan alur berlaku (Roslee et al. 2011). Selain itu, tanah yang mempunyai kandungan pasir yang tinggi memerlukan bahan organik yang tinggi kerana bahan organik akan membantu memperbaiki agregat tanah berpasir dan menyebabkannya kurang telap kepada air (Zulfahmi et al. 2007). Sifat semula jadi bahan organik yang mampu mengawal kandungan lembapan dan ikatan struktur dalam tanah boleh mempengaruhi kestabilan sesebuah cerun. Nilai pH pada sampel cerun Formasi Trusmadi dilihat lebih tinggi berbanding sampel cerun Formasi Crocker. Ini menunjukkan faktor pembentukan tanah memainkan peranan yang penting dalam keseimbangan nilai $\mathrm{pH}$ di dalam tanah. Dalam sistem semula jadi, nilai $\mathrm{pH}$ dipengaruhi oleh mineralogi, cuaca dan luluhawa (U.S Department of Agriculture (USDA) (1998). Tanah yang berpasir mempunyai keasidan yang tinggi. Tanah yang mempunyai kandungan pasir yang tinggi memerlukan bahan organik yang tinggi kerana bahan organik akan membantu memperbaiki agregat tanah berpasir dan menyebabkannya kurang telap kepada air (Zulfahmi et al. 2007).

\section{KESIMPULAN}

Kegagalan cerun jenis tanah (T) dan jenis khas atau hakisan (TB) yang berlaku di sepanjang RTM terbentuk disebabkan oleh beberapa faktor iaitu: kedalaman profil luluhawa tinggi; kekuatan bahan cerun terhadap agen luluhawa; kekurangan penutup tumbuhan pada permukaan cerun; pemotongan sudut kemiringan muka cerun $>45^{\circ}$; dan aliran air permukaan yang menyebabkan berlakunya hakisan. Formasi Trusmadi dilihat lebih cenderung mengalami kegagalan hakisan (TB) manakala Formasi Crocker kebanyakannya mengalami kegagalan jenis tanah (T). Kegagalan bahan cerun Formasi Trusmadi sebahagian besarnya dipengaruhi oleh litologi batuan dan kehadiran mineral lempung seperti kaolinit, ilit, vermikulit dan montmorilonit manakala kegagalan bahan cerun Formasi Crocker kebanyakannya dipengaruhi oleh faktor geologi seperti kesan ketakselanjaran dan aktiviti tektonik. Kehadiran mineral lempung menunjukkan litologi memainkan peranan yang penting dalam keseimbangan nilai $\mathrm{pH}$ tanah yang akan menggalakkan kesuburan ВОТ. Kadar luluhawa yang tinggi, litupan vegetasi yang sedikit serta perlindungan cerun yang tidak efisien menyebabkan kebarangkalian untuk terjadinya kejadian tanah runtuh berulang adalah tinggi. Oleh itu, pembinaan dan pengurusan kerja-kerja potongan cerun bukan sahaja perlu mengambil kira aspek sifat fizikal dan kejuruteraan tanah malah sifat kimia tanah juga amat penting terutamanya yang melibatkan batuan yang terluluhawa supaya kegagalan cerun potongan dapat ditangani sewajarnya.

\section{PENGHARGAAN}

Penulis ingin mengucapkan ribuan terima kasih dan penghargaan kepada para pensyarah dan pembantu makmal program Geologi UKM dan UMS dalam membantu menjayakan projek penyelidikan ini. Projek ini dibiaya menerusi geran FRGS/1/2014/STWN06/UKM/03/1 dan GUP-2014-031.

\section{RUJUKAN}

Acres, B.D., Bowen, R.P., Burrough, P.A., Folland, C.J., Kalsi, M.S., Thomas, P. \& Wright, P.S. 1975. The Soil of Sabah. Classification and description (with introduction to Vol. 1-5). Jil. 1. Land Resources Division, Ministry of Overseas Development Tolworth Tower, England. hlm. 134.

British Standard BS 1377. 1990. Methods of Test for Soils for Civil Engineering Purposes. Part 2: Classification test. London: British Standard Institution.

British Standard BS 1377. 1990. Methods of Test for Soils for Civil Engineering Purposes. Part 3: Chemical and electro-chemical tests. London: British Standard Institution.

Brown, E.T. 1981. ISRM Suggested Method. Rock Characterization Testing and Monitoring. Oxford: Pergamon Press.

Collenette, P. 1958. The Geology \& Mineral Resources of the Jeselton-Kinabalu Area, North Borneo. Memoir 6, Borneo Geological Survey Department.

Dahal, R.K., Hasegawa, S., Yamanaka, M., Dhakal, S., Bhandary, N.P. \& Yatabe, R. 2008. Comparative analysis of contributing parameters for rainfall-triggered landslides in the Lesser Himalaya of Nepal. Environment Geology. DOI 10.1007/ s00254-008-1531-6. Springer-Verlag.

Damanhuri Jamalluddin, Fauziah Ahmad \& Roslan Zainal Abidin. 2014. Characteristics of soil taken from slope failures in sedimentary and granitic residual soils. International Journal of Civil \& Environmental Engineering IJCEE-IJENS 14(06): 31-37.

Goh, T.L., Rafek, A.G. \& M. Hariri Arifin. 2012. Kekuatan geomekanik batuan granit dan syis di Semenanjung Malaysia. Sains Malaysiana 41(2): 193-198.

Goh, T.L., Rafek, A.G. \& M. Hariri Arifin. 2014. Korelasi pekali kekasaran kekar (JRC) dengan sudut geseran puncak satah ketakselanjaran batuan granit, Semenanjung Malaysia. Sains Malaysiana 43(5): 751-756.

Hamzah Hussin, Tajul Anuar Jamaluddin \& Muhammad Fadzli Deraman. 2015. Mode of slope failure of moderately to completely weathered metasedimentary rock at Bukit Panji, Chendering, Kuala Terengganu. Journal of Tropical Resources and Sustainable Science 3: 5-12.

IAEG. 1981. Rock and soil description and classification for engineering geological mapping. Bulletin of the International Association of Engineering Geology 24: 235-274.

Ibrahim Komoo. 1985. Pengelasan kegagalan cerun di Malaysia. Ilmu Alam 14 \& 15. Hlm. 47-58.

Ibrahim Komoo \& Mogana, S.N. 1988. Physical characterization of weathering profile of classic metasediment in Peninsular 
Malaysia. Proc. 2nd Int. Conf. Geomech. In Tropical Soil 1: $37-42$.

Ibrahim Komoo \& Lim, C.S. 2003. Kompleks gelinciran tanah Kundasang: Pemetaan terperinci di kawasan Sekolah Menengah Kebangsaan Kundasang. Geological Society of Malaysia Bulletin 46: 387-392.

Jacobson, G. 1970. Gunong Kinabalu area, Sabah, Malaysia. Geological Survey Malaysia. Report 8.

Liew, S.S. 2004. Slope failures in tropical residual soils. Tropical Residual Soils Engineering. hlm. 73-101.

Majid, M.F., Sanudin Hj. Tahir \& Zan, E.V.L. 1998. Preliminary report on slope stability of the Kota Kinabalu Tambunan Road, Sabah. Borneo Science 4: 11-26.

McKenna, J.P., Santi, P.M., Amblard, X. \& Negri, J. 2011. Effects of soil-engineering properties on the failure mode of shallow landslides. Landslides. Journal of the International Consortium on Landslides 3(1).

Munsell,A.H. 1941. A Color Notation. Munsell Soil Color Charts, Baltimore (Munsell Color Company Inc.).

Qasim, S., Harahap, I.S.H. \& Osman, S.B.S. 2013. Causal factors of Malaysian landslides: A narrative study. Research Journal of Applied Sciences, Engineering and Technology 5(7): 2303-2308.

Roslee, R., Sanudin Tahir \& S. Abd Kadir S. Omang. 2006. Engineering geology of the Kota Kinabalu area, Sabah, Malaysia. Geological Society of Malaysia Bulletin 52: 17-25.

Roslee, R., Sanudin Tahir, Nor Samihah Abdullah Zawawi, Hafzan Eva Mansor \& S. Abd. Kadir S. Omang. 2008. Engineering geological assessment on slope design in the mountainous area of Sabah Western, Malaysia: A Case Study from the Ranau-Tambunan, Penampang-Tambunan and Kimanis-Keningau Road. An International Conference on Recent Advances in Engineering Geology. Kuala Lumpur, Malaysia.

Roslee, R., Sanudin Tahir, Baba Musta \& Abd. Kadir S. Omang. 2010. Geological inputs for Landslide Hazard Identification (LHI) in the Trusmadi Formation slopes, Sabah, Malaysia. Borneo Science 26: 37-51.

Roslee, R., Sanudin Tahir, Baba Musta \& Abd. Kadir S. Omang. 2011. Geological inputs for landslide hazard identification (LHI) in the Trusmadi Formation slopes, Sabah, Malaysia. Borneo Science 29: 60-74.

Roslee, R., Sanudin Tahir, S. Abd. Kadir S. Omang \& Adong Laming. 2011. Survey of slope failures (SFS) along the Bundu Tuhan Kundasang Highway, Sabah, Malaysia. Borneo Science 29: 46-59.

Siti Nurshakiren. 2010. Pengaruh amang terhadap sifat-sifat geoteknik tanah baki metasedimen dan basalt. Tesis Sarjana Muda, Universiti Kebangsaan Malaysia (tidak diterbitkan).

Tajul Anuar, J. 2006. Faktor manusia dan kegagalan cerun di Malaysia. Geological Society of Malaysia Bulletin 52: 75-84.

Tan, B.K. 2004. Country case study: Engineering geology of tropical residual soils in Malaysia. In Tropical Residual Soils Engineering, edited by Huat, B.B.K., Gue, S.S., \& Ali, F.H. London: Taylor \& Francis. pp. 237-244.

Tongkul, F. 2007. Geological inputs in road design and construction in mountainous areas of West Sabah, Malaysia. Proc. of the 2nd Malaysia-Japan Symposium on Geohazards and Geoenvironmental Engineering. hlm. 39-43.

Tongkul, F. 2006. Geological influence on slope failures in the mountainous areas of West Sabah. International Conference on Slopes.
Tongkul, F. 1990. Structural styles and tectonics of Western and Northern Sabah. Bull. Geol. Soc. Malaysia 27: 227-240.

Tongkul, F. 1987. Sedimentology and structural of the Crocker Formation in the Kota Kinabalu area, Sabah. Tesis Dr. Fal. University of London, London (tidak diterbitkan).

U.S. Department of Agriculture (USDA). 1998. Soil Quality Indicators: $p H$. Soil Quality Information Sheet. Natural Resources Conservation Service, Washington, DC.

Vacondios, I., Konstantopoulou, G. \& Karadassi, St. 2007. The contribution of clay minerals in the landslide occurrences within Pindos Flysh Formation. Bulletin of the Geological Society of Greece vol. XXXX. (Proceedings of the 11 the International Congress, Athens).

Varnes, D.J. 1958. Landslide types and processes. In LandslidesAnalyses and Control, edited by Schuster, R. \& Krizek, R. T.R.B., National Academy of Sciences, Special Report 176: 11-33.

Yong, C.Y. 2008. Geologi am dan kajian kestabilan cerun sepanjang Jalan Kampung Peropot-Kampung Tontolob Liwan (KM13-KM25), Jalan Raya Ranau-Tambunan, Sabah. Tesis Sarjana Muda, Universiti Malaysia Sabah (tidak diterbitkan).

Zulfahmi,A.R. 1999. Structural pattern of the Crocker Formation in southern part of Beaufort Area, Sabah. Borneo Science 6: 11-20.

Zulfahmi, A.R., Sahibin, A.R., Jasni Yaakob \& Wan Muhd Razi Idris. 2007. Tinjauan awal potensi ketidakstabilan cerun dan cirian fiziko-kimia tanah di Cameron Highland, Pahang. Sains Malaysiana 36(2): 105-116.

Zulfahmi, A.R., Wan Zuhairi, W.Y., Raihan, M.T., Sahibin, A.R., Wan Mohd Razi, Tukimat, L., Siti Nur Syakireen, Z. \& Noorulakma, A. 2012. Influence of Amang (Tin Tailing) on geotechnical properties of clay soil. Sains Malaysiana 41(3): 303-312.

Noran Nabilla Nor Azlan, Norbert Simon* \& Azimah Hussin Program Geologi, Pusat Sains Sekitaran dan Sumber Alam Fakulti Sains dan Teknologi

Universiti Kebangsaan Malaysia

43600 UKM Bangi, Selangor Darul Ehsan

Malaysia

Rodeano Roslee

Jabatan Geologi, Fakulti Sains dan Teknologi

Universiti Malaysia Sabah, Jalan UMS

88400 Kota Kinabalu, Sabah Negeri di Bawah Bayu

Malaysia

Lee Khai Ern

Institut Alam Sekitar \& Pembangunan (LESTARI)

Universiti Kebangsaan Malaysia

43600 UKM Bangi, Selangor Darul Ehsan

Malaysia

*Corresponding author; email: norbsn@ukm.edu.my

Received: 26 May 2016

Accepted: 6 December 2016 